\title{
Simple reaction time: how it relates to body mass index (BMI), gender and handedness in Ghanaian students.
}

\author{
Ato Ampomah Brown', Leonard Derkyi-Kwarteng'2, Christian K Ackom ${ }^{3}$, Ernest Addae', \\ Francis Newton ${ }^{1}$ Dennis Amoah ${ }^{1}$ and Dennis Nartey Blemano ${ }^{1}$ \\ ${ }^{1}$ Department of Anatomy and Cell Biology, ${ }^{2}$ Department of Pathology, ${ }^{3}$ Department of \\ Psychology and Mental Health, School of Medical Sciences, University of Cape Coast
}

DOI: http://dx.doi.org/10.19106/JMedSci004901201701

\begin{abstract}
The purpose of this study was to examine the relationship between gender, handedness and body mass index (BMI) with simple reaction time. The study was conducted amongst 501 (232 females and 269 males) untrained University of Cape Coast students, Ghana whose ages ranged from 17-29 years. In this study it was found that males had faster reaction times than females, likewise the mean reaction time of the left hand was also faster than that of the right hand. There was however no significant difference in the mean reaction time across $\mathrm{BMI}$ classes In conclusion, simple reaction time is influenced by gender and handedness but appears not to be influence by BMI
\end{abstract}

\section{ABSTRAK}

Penelitian ini bertujuan untuk mengkaji hubungan antara jenis kelamin, penggunaan tangan dan indeks masa tubuh (IMT) dengan waktu reaksi sederhana. Penelitian dilakukan terhadap 501 (232 wanita dan 269 pria) pelajar Universitas Cape Coast, Ghana yang tidak terlatih yang berumur antara 17-29 tahun. Hasil penelitian ini meunjukkan bahwa pria waktu reaksi lebih cepat daripada wanita. Selain itu rerata waktu reaksi tangan kiri juga lebih cepat daripada tangan kanan. Namun demikian tidak ada perbedaan nyata rerata waktu reaksi antar kelompok IMT. Dapat disimpulkan, waktu reaksi sederhana dipengaruhi oleh jeniis kelamin dan penggunaan tangan tetapi tidak dipengaruhi IMT.

Keywords: simple reaction time - body mass index (BMI) - gender - handedness

\section{INTRODUCTION}

Reaction time (RT) is the interval between the onset of a signal (stimulus) and the initiation of a movement response. ${ }^{1}$ The measurement of reaction time has for a long time been of interest in certain sports such as the $100 \mathrm{~m}$ sprint in which reaction times (to the starter's gun) can be an important determinant of success, as races are often decided by hundredths of a second. ${ }^{2,3}$ In more recent times RT has come to the fore in the area of assessing sports concussions, which has become a big issue in contact sports. ${ }^{4}$ Various factors such as nutrition, training, age 
gender exercise, hand dominance and fatigue have been found to influence ones reaction time. $^{5-7}$

There is evidence to support assertion that some anthropometric measures may also have an effect of reaction time. Previous study showed that untrained young males with greater body mass index (BMI) had longer RT in response to simple stimuli than those who had lower BMI. ${ }^{8}$ In addition, another study also had similar findings in healthy young women. ${ }^{9}$ However, there is little to no information on this subject matter in Ghana. The aim of this study was to evaluate whether gender, handedness and BMI influence the simple reaction time in Ghanaian Students.

\section{MATERIALS AND METHOODS}

\section{Subjects}

The study involved 501 untrained university students whose ages ranged from 17-29 years; there were 232 females and 269 males. Informed consent was obtained from all participants. Subjects who were on psychotropic drugs (sedatives, hypnotics, and tranquilizers), antihistamines, and antiepileptics as well as individuals who had an active injury affecting the hand or arm were excluded from the study. The age and dominant hand of all participants were also recorded at the time of testing. The protocol of this study has been approved by the Health Research Ethics Committee of School of Medical Sciences, University of Cape Coast.

\section{Measurement of simple reaction time}

Simple reaction time which is a measure of how quickly an organism can respond to a single stimulus was measured by the technique described by Eckner et al. ${ }^{4}$ This method makes use of a $1.0 \mathrm{~m}$ long a measuring stick, embedded in a weighted rubber disk and marked in $0.5 \mathrm{~cm}$ increments. Participant sat with their forearm resting comfortably on a horizontal surface of a table, such that the proximal edge of the hypothenar eminence was positioned at the edge of table with the fingers overlapped the edge. The examiner suspended the apparatus vertically, with the weighted disk positioned inside the participants opened hand, such that the superior surface of the weighted disk was aligned with the plane of the first 2 digits and no part of the subject's hand was in contact with the weighted disk. The examiner released the apparatus at predetermined, randomly assigned time intervals of between 2 and 5 seconds to prevent the subject from anticipating the time of release. Subjects then caught the apparatus as quickly as possible as it began to fall. The fall distance was measured from the superior surface of the weighted disk to the most superior aspect of the subjects hand and was converted into a reaction time (in milliseconds) using the formula for a body falling under the influence of gravity $\left(\mathrm{d}=1 / 2 \mathrm{gt}^{2}\right)$, where ' $\mathrm{d}$ ' is distance, ' $\mathrm{g}$ ' is acceleration due to gravity, and ' $\mathrm{t}$ ' is time. The reaction time measurement was recorded for the dominant and non-dominant hand.

\section{Measurement of BMI}

The BMI which is a measure of body fat based on weight in relation to height was obtained by assistants who had been trained prior to the taking of measurements. Measurements were taken with respondents wearing lightweight clothing without shoes using seca 755 column scale. Height (m) was measured with a height seca 224 telescopic measuring rod attached to the seca column scale to the nearest $0.01 \mathrm{~cm}$ with respondents standing upright following standard protocol. Weight was measured to the nearest 0.5 $\mathrm{kg}$. the BMI was calculated as weight $(\mathrm{kg})$ divided by height squared $\left(\mathrm{m}^{2}\right)$. The weights 
were categorized using the WHO standard as follows; $18.5-24.9 \mathrm{~kg} / \mathrm{m}^{2}$ normal weight and $25.0-29.9 \mathrm{~kg} / \mathrm{m}^{2}$ overweight.

\section{Statistical analysis}

Data were expressed as mean \pm standard deviation (SD). The differeent between RT and the variables of interest (gender, handedness and BMI) were tested by t-test assuming equal variance. A $p$ value $<0.05$ was considered to be statistically significant. All data was analysed using SPSS version 19.0.

\section{RESULTS}

TABLE 1 shows that males had a faster mean RT time than females when testing either hand $(p<0.05)$. Furthermore, it was observed that right handed males had significantly faster mean RT than females when either hand is tested $(\mathrm{p}<0.05)$, no such statistically significant difference was observed in mean RT of left and right hands of left handed individuals (TABLE 2).

TABLE 1. Gender differences in reaction time

\begin{tabular}{lccr}
\hline \multicolumn{1}{c}{ Gender } & Male & Female & p \\
\hline Right Hand RT $(\mathrm{ms})$ & $196.1 \pm 41.4$ & $223.5 \pm 43.8$ & $<0.000$ \\
Left Hand RT $(\mathrm{ms})$ & $181.5 \pm 40.8$ & $210.7 \pm 48.8$ & $<0.000$ \\
\hline
\end{tabular}

TABLE 2. Gender differences in reaction time of right and left handed persons

\begin{tabular}{lcccccc}
\hline \multirow{2}{*}{ Gender } & \multicolumn{3}{c}{ Right Handed Persons } & \multicolumn{3}{c}{ Left Handed Persons } \\
\cline { 2 - 7 } & Male & Female & $\mathrm{p}$ & Male & Female & $\mathrm{p}$ \\
\hline Right Hand RT(ms) & $194.6 \pm 39.6$ & $225.6 \pm 44.4$ & $<0.000$ & $210.9 \pm 55.3$ & $199.8 \pm 29.9$ & 0.213 \\
Left hand RT (ms) & $180.6 \pm 40.4$ & $212.1 \pm 46.9$ & $<0.000$ & $192.5 \pm 44.7$ & $196.1 \pm 64.7$ & 0.415 \\
\hline
\end{tabular}

TABLE 3 shows that in both males and females the mean RT of the left hand was significantly faster than that of the right hand $(\mathrm{p}<0.05)$.

In TABLE 4 it was observed that for both male and female right handed individuals, mean RT of the left hand was significantly faster than that of the right hand $(\mathrm{p}<0.05)$.

In left handed individuals however there was no statistically significant difference when mean RT of the right hand was compared to the mean RT of the left hand.

TABLE 3. Reaction time difference between the left and right hand

\begin{tabular}{lccc}
\hline Gender & Right Hand RT $(\mathrm{ms})$ & Left Hand RT $(\mathrm{ms})$ & $\mathrm{p}$ \\
\hline Male & $196.1 \pm 41.4$ & $181.5 \pm 40.8$ & $<0.000$ \\
Female & $223.5 \pm 43.8$ & $210.7 \pm 48.8$ & 0.002 \\
\hline
\end{tabular}


TABLE 4. Reaction time difference between right and left hands of right and left handed persons

\begin{tabular}{lllrllr}
\hline \multirow{2}{*}{ Gender } & \multicolumn{3}{c}{ Right Handed Persons } & \multicolumn{4}{c}{ Left Handed Persons } \\
\cline { 2 - 7 } & Right Hand RT $(\mathrm{ms})$ & Left Hand RT $(\mathrm{ms})$ & $\mathrm{p}$ & \multicolumn{1}{c}{ Right Hand RT $(\mathrm{ms})$} & Left Hand RT (ms) & $\mathrm{p}$ \\
\hline Male & $194.6 \pm 39.6$ & $180.6 \pm 40.4$ & $<0.000$ & $210.9 \pm 55.3$ & $192.5 \pm 44.7$ & 0.111 \\
Female & $225.6 \pm 44.4$ & $212.1 \pm 46.9$ & 0.001 & $199.8 \pm 29.9$ & $196.1 \pm 64.7$ & 0.411 \\
Total & $209.0 \pm 44.6$ & $195.1 \pm 46.3$ & $<0.000$ & $205.7 \pm 45.1$ & $194.2 \pm 54.3$ & 0.142 \\
\hline
\end{tabular}

No significant difference was observed in the mean RT of the left hand when mean RT of right handed persons was compared to that of right handed persons (TABLE 5). Mean RT of the right hand was significantly shorter in right handed males as compared to left handed males $(p<0.05)$. In female however the mean
RT of the right hand was faster in left handed females than right handed females $(p<0.05)$. TABLE 6 shows that in both males and females there was no significant difference in the mean RT of overweight persons compared to normal weight persons.

TABLE 5. Reaction time difference between right handed and left handed individuals

\begin{tabular}{lcccccc}
\hline \multirow{2}{*}{ Gender } & \multicolumn{3}{c}{ Left Hand RT $(\mathrm{ms})$} & \multicolumn{3}{c}{ Right Hand RT (ms) } \\
\cline { 2 - 7 } & $\begin{array}{c}\text { Left handed } \\
\text { Persons }\end{array}$ & $\begin{array}{c}\text { Right Handed } \\
\text { Persons }\end{array}$ & $\mathrm{p}$ & $\begin{array}{c}\text { Left Handed } \\
\text { Persons }\end{array}$ & $\begin{array}{c}\text { Right Handed } \\
\text { Persons }\end{array}$ & $\mathrm{p}$ \\
\hline Male & $192.5 \pm 44.7$ & $180.6 \pm 40.4$ & 0.091 & $210.9 \pm 55.3$ & $194.6 \pm 39.6$ & 0.036 \\
Female & $196.1 \pm 64.7$ & $212.1 \pm 46.9$ & 0.081 & $199.8 \pm 29.9$ & $225.6 \pm 44.4$ & 0.006 \\
Total & $194.2 \pm 54.3$ & $195.1 \pm 46.3$ & 0.497 & $205.7 \pm 45.1$ & $209.0 \pm 44.6$ & 0.322 \\
\hline
\end{tabular}

TABLE 6. Reaction time difference between normal weight and overweight persons

\begin{tabular}{lccccccc}
\hline \multirow{2}{*}{ Gender } & \multicolumn{3}{c}{ Male } & \multicolumn{3}{c}{ Female } \\
\cline { 2 - 7 } & Normal & Overweight & $\mathrm{p}$ & Normal & Overweight & $\mathrm{p}$ \\
\hline Right Hand RT (ms) & $195.6 \pm 41.25$ & $202.5 \pm 36.36$ & 0.197 & $225.9 \pm 43.43$ & $232.4 \pm 36.99$ & 0.182 \\
Left Hand RT (ms) & $181.5 \pm 40.84$ & $179.1 \pm 38.14$ & 0.383 & $208.6 \pm 47.45$ & $208.1 \pm 49.09$ & 0.475 \\
\hline
\end{tabular}

\section{DISCUSSION}

\section{Body mass index}

In this study there was no significant difference in the mean RT of overweight males and normal weight male. The same was also observed in the female subgroup. These findings contradict those of Skurvydas et al. ${ }^{8}$ who found a longer reaction time in overweight young males as compared to their normal weight counterparts. The technique used to measure the RT in the two studies differed and that may have accounted for this observation. Skurvydas et al., ${ }^{8}$ employed the use of computer and a joystick while this present research utilised the measuring stick technique as described by Eckner et al., ${ }^{4}$ Perhaps the measuring technique used in this study may be more suitable in measuring RT of participants particularly where the weight 
of individuals may be a confounding factor. Further research in this area is therefore needed.

\section{Gender}

Literature reports that across almost every age group, males have faster reaction times than females, and that the female disadvantage is not reduced by practice. ${ }^{5,10,11}$ This was the observation in this study; with males having a faster RT time than females when testing either hand $(p<0.05)$. Some reasons have been given for this observation with some researchers attributing this difference to the lag between the presentation of the stimulus and the beginning of muscle contraction. ${ }^{12}$ When subjects were segregated by handedness, is was found that in right handed persons, males had statistically significant faster reaction time than females when either hand was tested $(p<0.05)$. There was however no statistically significant difference in mean RT when gender comparison was made in left handed persons, a finding similar to those of Dane et al. ${ }^{11}$ who found that even though right-handed male handball players had faster reaction times than right-handed females, there was no such sexual difference between left-handed male and female players. This finding suggests that left-handed females have reaction times that are comparable to left handed males. As such, though it is generally accepted that the males have faster RT than females in the generally population, this may assertion may not hold true for some subgroups within the population.

\section{Left versus right hand}

In both males and females the mean RT of the left hand was shorter than of the right hand $(p<0.05)$. This observation concurs with those of previous studies. ${ }^{13-15}$ This phenomenon has been attributed to the manner in which the central nervous system is set up to bring about movements in the body; with the left hemispheres of the cerebrum (which is responsible for as the verbal and logical brain) controlling the right hand and the right hemisphere (which is the thought to govern creativity, spatial relations and emotions) controlling the left hand. ${ }^{7}$ This has made researchers to believe that if the reaction time involves spatial relationships, then the left hand should be faster than the right hand. ${ }^{7}$ When subjects were grouped according to handedness it was found that in right handed individuals the RT of the left hand was faster than the right hand in both genders $(p<0.05)$. A finding contrary to those of Peters and Ivanoff ${ }^{16}$ who found that RT was shorter in the right hand than the left hand.

In left handed persons (both and male and female subgroups) the difference in right and left hand RT was statistically non-significant, a finding similar to those Peters and Ivanoff. ${ }^{16}$ This finding is worth noting as it does not follow the general trend where the left hand has a significantly shorter RT. Perhaps the bridging of the gap in mean RT between the right and left hand in this instance is due to use and disuse of the right and left hands respectively. In the Ghanaian society the use of the left hand is culturally frown upon, most Ghanaian children are trained to use the socially preferable right hand at all times, this probably, may be the reason for this observed variation in this subgroup of the population.

\section{Handedness}

In testing mean RT of the left hand, right handed individuals were found to have reaction times that were not significantly different from those of left handed individuals, this finding differs from those of Dane et al., ${ }^{11}$ who found that in handball players, 
reaction time in the left hand was faster for left handed player as compared to right handed players. Measurement of mean RT of the right hand showed that right handed males had a significantly shorter RT than left handed males $(p<0.05)$. However in female subgroup the reverse was observed, where the mean RT of the right hand was faster in left handed females than right handed females $(p<0.05)$. This observation suggests that in terms of having fast reaction times being left handed and female confers certain inherent advantages.

\section{CONCLUSION}

The reaction of people appears to be influenced by gender and handedness and these need to be noted when taking simple RT measurement, whereas BMI appears not to influence simple RT measurements in both sexes.

\section{ACKNOWLEDGEMENTS}

Authors would like to thank all students who participated in this study.

\section{REFERENCES}

1. Senel O \& Eroglu H. Correlation between reaction time and speed in elite soccer players. J Exerc Sci Fit 2006; 4(2):126-30.

2. Spierer DK, Petersen RA, Duffy K. Response time to stimuli in division I soccer players. J Strength Cond Res 2011;25(4):1134-41.http:// dx.doi.org/ 10.1519/ JSC.0b013e3181d09e4c

3. Tønnessen E, Haugen T, Shalfawi SA. Reaction time aspects of elite sprinters in athletic world championships. J Strength Cond Res 2013; 27(4):885-92. http://dx.doi. org/10.1519/ JSC.0b013e31826520c3

4. Eckner JT, Kutcher JS, Richardson JK. Pilot evaluation of a novel clinical test of reaction time in national collegiate athletic association division I football players. J Athl Train 2010; 45:327-32. http://dx.doi.org/10.4085/10626050-45.4.327 https://doi.org/10.4085/1062-6050-45.4.327

5. Der G \& Deary IJ. Age and sex differences in reaction time in adulthood: results from the United Kingdom health and lifestyle survey. Psychol Aging 2006; 21(1):62-73. https://doi.org/10.1037/0882-7974.21.1.62

6. Cote KA, Milner CE, Smith BA, Aubin AJ, Greason TA, Cuthbert BP, et al. CNS arousal and neurobehavioral performance in a shortterm sleep restriction paradigm. J Sleep Res 2009; 18(3):291-303. http://dx.doi.org/ 10.1111/j.1365-2869.2008.00733.x

https://doi.org/10.1111/j.13652869.2008.00733.x

7. Kosinski J. A literature review on reaction time. Clemson University; 2012. Available from: http://biology.clemson.edu/bpc/bp/ Lab/110/reaction.htm

8. Skurvydas A, Gutnik B, Zuoza AK, Nash D, Zuoziene IJ, Mickeviciene D. Relationship between simple reaction time and body mass index. Homo 2009; 60(1):77-85.

https://doi.org/10.1016/j.jchb.2008.06.006 http://dx.doi.org/10.1016/j.jchb.2008.06.006 https://doi.org/10.1016/j.jchb.2008.06.006

9. Nene AS, Pazare PA, Sharma KD. A study of relation between body mass index and simple reaction time in healthy young females. Indian J Physiol Pharmacol. 2011; 55(3):288-91.

10. Adam J, Paas FG, Buekers MJ, Wuyts IJ, Spijkers WA, Wallmeyer P. Gender differences in choice reaction time: evidence for differential strategies. Ergonomics 1999; 42(2):327-35. https://doi.org/10.1080/001401399185685

11. Dane S, ErzurumluogluA. Sex and handedness differences in eye-hand visual reaction times in handball players. Int J Neurosci 2003; 113(7):923-9. https://doi.org/10.1080/00207450390220367 
12. Botwinick J, Thompson LW. Components of reaction time in relation to age and sex. $\mathrm{J}$ Genet Psychol 1966; 108(2d Half):175-83.

13. Boulinguez $\mathrm{P}$, Barthélémy S, Debu B. Influence of the movement parameter to be controlled on manual RT asymmetries in right-handers. Brain Cogn 2000; 44(3):65361. http://dx.doi.org/10.1006/brcg.2000.1234 https://doi.org/10.1006/brcg.2000.1234

14. Barthélémy S, Boulinguez P. Manual reaction time asymmetries in human subjects: the role of movement planning and attention. Neurosci Lett 2001; 315(1):41-4.

https://doi.org/10.1016/S0304-3940(01) 02313-8
15. Barthélémy S, Boulinguez P. Orienting visuospatial attention generates manual reaction time asymmetries in target detection and pointing. Behav Brain Res 2002; 133(1):109-16.

https://doi.org/10.1016/S0166-4328(01) 00446-6

16. Peters M, Ivanoff J. Performance asymmetries in computer mouse control of righthanders, and left handers with left- and right-handed mouse experience. J Mot Behav 1999; 31(1):86-94. http://dx.doi.org/10.1080/ 00222899909601894 https://doi.org/10.1080/00222899909601894 